\title{
Gender differences in suicide attempts: preliminary results of the multisite intervention study on suicidal behavior (SUPRE-MISS) from Campinas, Brazil Diferenças entre os sexos nas tentativas de suicídio: resultados iniciais do estudo multicêntrico de intervenção no comportamento suicida (SUPRE-MISS) obtidos em Campinas, Brasil
}

\author{
Sabrina Stefanello, ${ }^{1}$ Carlos Filinto da Silva Cais, ${ }^{1}$ Marisa Lúcia Fabricio Mauro, ${ }^{1}$ \\ Gisleine Vaz Scavacini de Freitas, ${ }^{1,2}$ Neury José Botega ${ }^{1}$
}

\begin{abstract}
Objective: To identify sociodemographic, psychosocial and clinical differences between men and women who attempted suicide and were seen at a university general hospital. Method: This is a non-controlled cross-sectional study, sub-project of the Multisite Intervention Study on Suicidal Behavior by the World Health Organization. A standardized interview that comprised psychometric scales was used. The comparison between genders was made by means of uni and multivariate logistic regression. Results: 210 subjects (68. $1 \%$ women) participated. Women had worse scores on the WHO Well-Being Index ( $p=0.005)$, the Beck Depression Inventory ( $p=0.01)$ and the Psychiatric Disability Assessment Schedule ( $p=0.03)$. In the multivariate logistic regression, men presented more mental disorders due to alcohol and drug use (26.1\% vs 7\%, $p=0.02)$ and used alcohol at the suicide attempt more frequently (28.3\% vs $16 \%$, $p=0.03)$. Men reported that most of the time they had been feeling "active and vigorous" (50\% vs 22\%, $p<0.001$ ). Women had had more physical and sexual abuse (27\% vs $8.7 \%, p=0.01)$. Conclusion: There are some distinctive characteristics between men and women who attempt suicide. Such differences may also be present in the general population and suggest there is a need for further studies, as well as the adoption of different strategies in suicide prevention for men and women.
\end{abstract}

Descriptors: Suicide, attempted; Suicide; Gender; Primary prevention; Mental health

\section{Resumo}

Objetivo: Identificar diferenças entre os sexos em variáveis sociodemográficas, psicossociais e clínicas em indivíduos que tentaram o suicídio e foram atendidos em um hospital geral universitário. Método: Estudo transversal não-controlado, subprojeto do Estudo Multicêntrico de Intervenção no Comportamento Suicida, da Organização Mundial de Saúde. Utilizou-se uma entrevista padronizada, incluindo escalas psicométricas. A comparação entre os sexos foi feita usando-se regressão logística uni e multivariada. Resultados: Dos 210 sujeitos, 143 (68,1\%) foram do sexo feminino. As mulheres tiveram piores escores no Indice de Bem-Estar OMS ( $p=0,005$ ), na escala de Beck de Depressão $(p=0,01)$ e na escala de Desempenho do Papel Social $(p=0,03)$. Na regressão logística multivariada, encontraram-se mais problemas por uso de álcool e drogas entre os homens $(26,1 \% \mathrm{vs} 7 \%, p=0,02)$. Estes se valeram mais dessas substâncias na tentativa de suicídio $(28,3 \%$ vs $16 \%, p=0,03)$ e relataram que "vinham se sentindo vigorosos" a maior parte do tempo (50\% vs 22\%, $p<0,001)$. Mulheres relataram ter sofrido mais abuso físico e sexual (27\% vs 8, 7\%, p = 0,01). Conclusão: Encontraram-se algumas características distintas entre homens e mulheres que tentaram suicídios. Tais diferenças, que podem estar igualmente presente na população geral, sugerem novos estudos e a adoção de diferentes estratégias visando à prevenção do suicídio entre homens e mulheres.

Descritores: Tentativa de suicídio; Suicídio; Sexo; Prevenção primária; Saúde mental

\footnotetext{
1 Department of Medical Psychology and Psychiatry, School of Medicine, Universidade Estadual de Campinas (Unicamp), Campinas (SP), Brazil

2 Faculdade de Psicologia, Universidade Metodista, Piracicaba (SP), Brazil
}

Financial support: The study was funded by the Department of Mental Health and Substance Abuse, World Health Organization (grant $n^{\circ}$ M4/445/119) and Fundação de Amparo à Pesquisa do Estado de São Paulo (FAPESP), Grant $n^{\circ}$ 02/08288-9.

Conflict of interests: None

Submitted: July 5, 2007

Accepted: October 15, 2007
Correspondence

Departamento de Psicologia Médica e Psiquiatria, FCM-UNICAMP

Caixa Postal 6111

13081-970 Campinas, SP, Brasil

Phone/fax: (55 19) 3521-7038

E-mail: sabrinas@fcm.unicamp.br 


\section{Introduction}

A nonfatal suicide attempt and a mental disorder are the strongest known clinical predictors of eventual suicide. ${ }^{1,2}$ During the last years, suicide numbers are increasing around the world, including Brazil, especially in younger persons and adult men. ${ }^{3}$ In most countries, men commit more suicide and women make more suicide attempts: this is called the gender paradox. ${ }^{4}$ There are some exceptions, like China, where women commit more suicide than men and few places such as India, Singapore, Hong Kong, Kuwait and Japan where the suicidal behavior has almost the same figures between both genders. ${ }^{5}$

Some theories try to explain the gender paradox in suicidal behavior. ${ }^{4}$ The first one is related to the method: men tend to use violent methods that are more lethal. ${ }^{4}$ The second is about the different prevalence of depression and alcohol abuse between the genders. It also includes the fact that women seek treatment more often and this would prevent suicide. ${ }^{4}$ The socialization theory suggests that both genders tend to adopt self-destructive behavior according to their cultural backgrounds. Accordingly, suicide attempts would be "more acceptable" among females. ${ }^{4}$

Besides this striking difference between genders, other factors that influence suicidal behavior are dependent on gender. Men seem to suffer more with economic, health and employment problems. ${ }^{6}$ They also have more history of aggressive and antisocial behavior. ${ }^{7}$ The two years following pregnancy protects women from suicidal behavior. ${ }^{6}$ On the other hand, they have more history of sexual abuse, especially during childhood. ${ }^{8}$

There are few national studies about differences on suicidal behavior between the genders. The most frequent difference pointed out is that men commit 2-3 times more suicide than women, while women attempt suicide more often. ${ }^{9}$ Other differences observed were: a) age: among suicide attempters women are younger; b) occupational status: more unemployment among men, and more students, housewives and retirees among women. ${ }^{10}$ The objective of this study was to identify gender differences in clinical, psychosocial and sociodemographic variables among those who attempted suicide.

\section{Method}

This was a cross-sectional study derived from the Campinas data of the Multisite Intervention Study on Suicidal Behavior (SUPREMISS) launched by the World Health Organization in 2000 to evaluate an innovative intervention in a large randomized controlled trial. It brought together the elements of information, education, and practical advice from brief interventions maintaining long-term follow-up contact with suicide attempters on a regular basis. ${ }^{11-13}$

Campinas is located in the State of São Paulo. It has approximately 1 million inhabitants, over $98 \%$ of them living in the urban area. The study was carried out at the Hospital de Clínicas of the Universidade Estadual de Campinas (HC UNICAMP), which receives patients from several neighboring cities. It provides emergency care for approximately $40 \%$ of the population of Campinas.

Suicide attempters were identified between October 2002 and August 2004. To be considered a suicide attempter, the individual should be aware that the act was a threat to his/her life. ${ }^{14}$ The study was approved by the ethics committee of the institution. All subjects enrolled in the study agreed to participate and signed a consent form.

An attempt was made to include all suicide attempters seen at the emergency room or admitted to the surgical and medical wards of the hospital. The exclusion criteria were age below 14 years old and inability to answer the questionnaire. All the interviews were made face-to-face by 5 trained psychiatrists and 2 social workers. Most interviews (95\%) were made at the emergency room just after the psychiatric evaluation. Some patients (5\%) were seen later, after recovery, at the wards. When the psychiatric staff was aware of a suicide attempt, the researcher was communicated by pager or cell phone. There were interviewers assigned to cover 24 hours a day, seven days a week.

The questionnaire was based on the European Parasuicide Study Interview Schedule (EPSIS), of the WHO/EURO Multicentre Study on Suicidal Behaviour. ${ }^{4}$ The questionnaire covered a series of sociodemographic, psychosocial, clinical variables, and instruments that have been validated in Brazil, such as the Suicide Intent Scale, the Beck Depression Inventory, the WHO Well-Being Index, the Spielberger Trait-Anger Scale, the Bille-Brahe Measurement of Social Support, and the Psychiatric Disability Assessment Schedule. The syndromic diagnosis was made by the psychiatric staff (psychiatry resident and supervisor) on duty at the emergency room and coded according to ICD-10.

According to our review of the literature on suicide attempts, only those variables that could disclose differences between the genders were considered in the statistical analysis. Uni and multivariate logistic regression analyses with stepwise selection were used to get a differentiated profile of genders, taking the female gender as reference. Continuous variables were dichotomized using median values. All variables in the univariate analysis were included in the final logistic regression. The Statistical Analysis System (SAS) version 8.02 was used.

\section{Results}

Two hundred and twenty-nine subjects attempted suicide during he recruitment period and were approached by the research team. Sixteen were excluded because they could not answer the questionnaire at the first approach and were discharged before a new attempt of evaluation could be made. One patient refused to participate. Two individuals, who declared to be transsexuals, were excluded from the present analysis. One hundred and fortythree $(68.1 \%)$ out of the 210 subjects included were women, with mean age of 32 years old $(S D=13)$. The mean age for men was 33 years old $(S D=13)$. Fifty percent of the men and $39 \%$ of the women were married. The rate between female and male genders was $3.1: 1$. Most subjects were living with someone $(90.3 \%)$ and $47.3 \%$ had a job. Both men and women mostly used overdoses of sedative medication (39.4\% and $57.4 \%$ ) and pesticide ingestion ( $19.7 \%$ and $7.1 \%$, respectively). Table 1 shows the results of the uni and multivariate logistic regression.

\section{Discussion}

There were some distinctive characteristics between men and women who attempted suicide. Men used more psychoactive substances, mainly alcohol, including alcohol intake at the moment of the suicide attempt. Many of them (50\%) answered they had been feeling "active and vigorous" most part of the time. Women reported more sexual and physical abuse in the past.

The main limitation of this report is that, because it did not include a control group, we cannot state whether the differences found are typical of those who attempted suicide or similar to the differences observed among men and women in general, or even among those who are seen in health services. Thus our findings may 
Table 1 - Uni and multivariate logistic regression analyses (men vs. women)*

\begin{tabular}{|c|c|c|c|c|c|}
\hline Variables & Men n (\%) & Women n (\%) & $\mathrm{OR}^{\dagger}$ & $95 \% \mathrm{CI} \mathrm{OR}^{\ddagger}$ & p-value \\
\hline \multicolumn{6}{|l|}{ Univariate analysis } \\
\hline \multicolumn{6}{|l|}{ School attendance } \\
\hline Yes & $6(9.1)$ & $34(23.8)$ & 1.00 & - & - \\
\hline No & $60(90.9)$ & $109(76.2)$ & 3.12 & $1.24-7.85$ & 0.016 \\
\hline \multicolumn{6}{|l|}{ Years of study } \\
\hline$\geq 5$ years & $42(64.6)$ & $96(77.4)$ & 1.00 & - & - \\
\hline Until 4 years & $23(35.4)$ & $28(22.6)$ & 1.88 & $0.97-3.63$ & 0.061 \\
\hline \multicolumn{6}{|l|}{ Church frequency } \\
\hline Once a week & $14(22.6)$ & $61(45.2)$ & 1.00 & - & - \\
\hline Once a month & $11(17.7)$ & $13(9.6)$ & 3.69 & $1.37-9.93$ & 0.010 \\
\hline 1-3 times/year & $14(22.6)$ & $18(13.3)$ & 3.39 & $1.37-8.41$ & 0.009 \\
\hline Never & $23(37.1)$ & 43 (31.9) & 2.33 & $1.08-5.04$ & 0.031 \\
\hline \multicolumn{6}{|l|}{ Physical consequence of suicide attempt } \\
\hline None & $16(24.2)$ & $53(37.6)$ & 1.00 & - & - \\
\hline No danger of death & $18(27.3)$ & $48(34.0)$ & 1.24 & $0.57-2.71$ & 0.585 \\
\hline Risk of death & $31(48.5)$ & $40(28.4)$ & 2.65 & $1.28-5.48$ & 0.009 \\
\hline \multicolumn{6}{|l|}{ Treatment received } \\
\hline No special care required & $15(25.0)$ & $35(26.9)$ & 1.00 & - & - \\
\hline Care at emergency room & $12(20.0)$ & $45(34.6)$ & 0.62 & $0.26-1.50$ & 0.290 \\
\hline Intensive care & $21(35.0)$ & $22(16.9)$ & 2.23 & $0.95-5.21$ & 0.065 \\
\hline Psychiatric institution & $12(20.0)$ & $28(21.6)$ & 1.00 & $0.40-2.48$ & 0.999 \\
\hline \multicolumn{6}{|l|}{ Previous suicide attempt } \\
\hline Yes & $22(33.8)$ & $82(41.8)$ & 1.00 & - & - \\
\hline No & $43(66.2)$ & $59(58.2)$ & 2.72 & $1.47-5.02$ & 0.001 \\
\hline \multicolumn{6}{|l|}{ Self-pity after suicide attempt } \\
\hline Yes & $8(61.9)$ & $52(35.8)$ & 2.91 & $1.08-7.85$ & 0.034 \\
\hline No & $13(38.1)$ & $29(64.2)$ & 1.00 & - & - \\
\hline \multicolumn{6}{|l|}{ Previous psychiatric treatment } \\
\hline Yes & $32(50.0)$ & $92(65.7)$ & 1.00 & - & - \\
\hline No & $32(50.0)$ & $48(34.3)$ & 1.92 & $1.02-3.05$ & 0.034 \\
\hline \multicolumn{6}{|l|}{ Sexual and/or physical abuse } \\
\hline Yes & $5(7.9)$ & $37(26.4)$ & 1.00 & - & - \\
\hline No & $58(92.1)$ & $103(73.6)$ & 4.17 & $1.55-11.18$ & 0.005 \\
\hline \multicolumn{6}{|l|}{ Sexual and/or physical threat } \\
\hline Yes & $11(17.5)$ & $50(36.0)$ & 1.00 & - & - \\
\hline No & $52(82.5)$ & $89(64.0)$ & 2.66 & $1.27-5.55$ & 0.009 \\
\hline \multicolumn{6}{|c|}{ Alcohol or drug consumption at suicide attempt } \\
\hline Yes & $46(69.7)$ & $122(87.1)$ & 1.00 & - & - \\
\hline No & $20(30.3)$ & $18(12.9)$ & 2.95 & $1.43-6.06$ & 0.003 \\
\hline \multicolumn{6}{|c|}{ Mental disorder for psychoactive substance use } \\
\hline Yes & $44(68.7)$ & $123(93.2)$ & 1.00 & - & - \\
\hline No & $20(31.3)$ & $9(6.8)$ & 6.21 & $2.63-14.66$ & $<0.001$ \\
\hline \multicolumn{6}{|l|}{ Alcohol frequent use } \\
\hline Yes & $45(72.6)$ & $103(94.5)$ & 1.00 & - & - \\
\hline No & $17(27.4)$ & $6(5.5)$ & 6.48 & $2.40-17.53$ & $<0.001$ \\
\hline Affective disorder & & & & & \\
\hline Yes & $20(34.4)$ & $76(57.6)$ & 1.00 & - & - \\
\hline No & $44(65.6)$ & $56(42.4)$ & 2.29 & $1.39-4.82$ & 0.003 \\
\hline Beck Depression Inventory & & & & & \\
\hline Positive (> median) & $21(40.4)$ & $55(51.9)$ & 1.00 & - & - \\
\hline Negative ( $\leq$ median) & $31(59.6)$ & $51(48.1)$ & 1.59 & $0.81-3.12$ & 0.175 \\
\hline Difficulties at work/school over the la & & & & & \\
\hline Negative & $27(41.5)$ & $78(56.9)$ & 1.00 & - & - \\
\hline Positive & $38(58.5)$ & $59(43.1)$ & 1.86 & $1.02-3.38$ & 0.042 \\
\hline Health problems over the last year & & & & & \\
\hline Positive & $3(4.6)$ & $21(15.0)$ & 1.00 & - & - \\
\hline Negative & $62(95.4)$ & $119(85.0)$ & 3.65 & $1.05-12.70$ & 0.042 \\
\hline WHO Well-Being Index & & & & & \\
\hline Low/Bad ( $\leq$ median) & $19(36.5)$ & $68(59.1)$ & 1.00 & - & - \\
\hline High/Good (> median) & $33(63.5)$ & $47(40.9)$ & 2.51 & $1.28-4.94$ & 0.008 \\
\hline WHO Well-Being Index question: "fee & & & & & \\
\hline less than half of the time & $24(46.2)$ & $94(78.3)$ & 1.00 & -- & - \\
\hline most part of the time & $28(53.8)$ & $26(21.7)$ & 4.22 & $2.10-8.74$ & $<0.001$ \\
\hline
\end{tabular}

(To continue) 


\begin{tabular}{|c|c|c|c|c|c|}
\hline High (> median) & $22(33.8)$ & $74(53.6)$ & 1.00 & - & - \\
\hline Low ( $\leq$ median) & $43(66.2)$ & $64(46.4)$ & 2.26 & $1.22-4.17$ & 0.009 \\
\hline \multicolumn{6}{|l|}{ Multivariate Analysis ${ }^{\star \star}$} \\
\hline \multicolumn{6}{|l|}{ Alcohol or drug use at suicide attempt } \\
\hline No & $33(71.7)$ & $84(84.0)$ & 1.00 & - & - \\
\hline Yes & $13(28.3)$ & $16(16.0)$ & 2.94 & $1.09-7.95$ & 0.033 \\
\hline Yes & $12(26.1)$ & $7(7.0)$ & 3.65 & $1.2-11.08$ & 0.022 \\
\hline \multicolumn{6}{|l|}{ Sexual and/or physical abuse } \\
\hline Yes & $4(8.7)$ & $27(27.0)$ & 1.00 & - & - \\
\hline No & $42(91.3)$ & $73(73.0)$ & 4.44 & $1.33-14.89$ & 0.016 \\
\hline \multicolumn{6}{|c|}{ WHO Well-Being Index question: "feeling active and vigorous" } \\
\hline less than half of the time & $23(50.0)$ & $78(78.0)$ & 1.00 & - & - \\
\hline
\end{tabular}

*Univariate group: women ( $n=143)$ men $(n=67)$; multivariate group: women $(n=100)$ men $(n=46)$ ${ }^{* *}$ Only variables with statistically significant results are shown

${ }^{\dagger}$ OR $=$ Odds Ratio for male sex

$\mp$ 95\% $\mathrm{Cl}=95 \%$ Confidence Interval

not reflect the gender differences observed exclusively among suicide attempters. The results cannot be generalized to the overall population who attempt suicide as well. At a community level, the SUPRE-MISS epidemiological survey carried out in the same city showed that only one out of tree individuals who attempted suicide was seen at a medical service. ${ }^{12}$ Moreover, although we made efforts to approach all suicide attempters seen at the hospital consecutively, it is possible that cases of lower lethality were missed. As far as we can estimate, the research team failed to make contact with a minority of these cases, most of them due to early discharge.

Uni and multivariate logistic analyses were used in this report with the aim of finding the profile (group of variables) that best discriminates the differences between the genders. In this respect, the odds ratio (OR, Table 1) does not have the usual meaning found in studies that compare risk and control groups. Logistic regression can also overcome the problem of type 1 error in multiple comparisons. ${ }^{15}$

Probably due to sample size, some well-known gender differences were not statistically significant, such as violence of suicide method and antisocial behavior, both being more frequent among men. Moreover, as the interview was made at a crisis situation, this may have caused similar answers (ceiling effect due to overreaction) and may not have elicited some differences between the genders.

In this respect, we did not observe the usually higher scores among women in the Beck Depression Inventory. Men had better performance on the WHO Well-Being Index and the Psychiatric Disability Assessment Schedule, although their suicide attempts needed intensive care and involved higher risk of death more frequently. One possible explanation for this is that aggressive behavior and alcohol abuse might mask depression symptoms among men. ${ }^{16}$ As mentioned above, cultural differences between men and women in general may have influenced our results, which are not exclusive of those who attempt suicide. A cultural bias should also be considered: men could have more difficulties to admit having life problems and difficulties that indicate "weakness".

Women, depending on the cultural background, seem to have a more condemnatory attitude towards suicide. ${ }^{17}$ Therefore, this attitude associated with other variables, like religiosity and search for treatment, may protect them from a fatal suicidal behavior. They also tend to perceive problems as personal and seek help at the health system, whereas males usually see their distress as a result of economic or social problems, deny depression and tend to make abusive use of alcohol. ${ }^{17}$

Overall, men had more self-pity after a prior suicide attempt and, although with no statistically significance, felt more shame of themselves than women. These feelings might reflect the unacceptability to survive after a suicidal act among men, seen as a failure, since suicide seems to be a more "masculine" behavior. $^{17}$

This study was exploratory in it is nature and the interpretation of our findings cannot be more than conjectural serving as clues for further research in the context of suicidal behavior. Taking this into consideration, studies about social and cultural aspects of female and male distinctive characteristics may contribute to increase our understanding on this topic. For the purpose of suicide prevention, specific strategies should be developed taking these distinctive characteristics into account. An active effort could be made to include men in mental health treatment, with focus on alcohol abuse, while for women the provision of effective treatment for depression associated with therapeutic techniques to handle crises may help prevent suicide attempts.

\section{Acknowledgements}

We are grateful to Eliza Omai and Helymar da Costa Machado for the statistical analysis.

\section{References}

1. Harris EC, Barraclough B. Suicide as an outcome for mental disorders. A meta-analysis. Br J Psychiatry. 1997;170:205-28.

2. Bertolote JM, Fleischmann A. Suicide and psychiatric diagnosis: a worldwide perspective. World Psychiatry. 2002;1(3):181-5.

3. WHO. Figures and facts about suicide. Geneve: World Health Organization; 1999.

4. Canetto SS, Sakinofsky I. The gender paradox in suicide. Suicide Life Threat Behav. 1998;28(1):1-23.

5. Cheng ATA, Lee CS. Suicide in Asia and the Far East. In: Hawton K, Heeringen Kv, editors. Suicide and Attempted Suicide. Chichester: John Wiley \& Sons; 2000. p. 29-48. 
6. Qin P, Agerbo E, Westergard-Nielsen N, Eriksson T, Mortensen PB. Gender differences in risk factors for suicide in Denmark. $\mathrm{Br} \mathrm{J}$ Psychiatry. 2000;177:546-50.

7. Krakowski M, Czobor P. Gender differences in violent behaviors: relationship to clinical symptoms and psychosocial factors. Am J Psychiatry. 2004;161(3):459-65.

8. Roy A, Janal M. Gender in suicide attempt rates and childhood sexual abuse rates: is there an interaction? Suicide Life Threat Behav. 2006;36(3):329-35.

9. Pietro D, Tavares M. Risk factors for suicide and suicide attempt: incidence, stressful events and mental disorders. J Bras Psiquiatr. 2005;54(2):146-54.

10. Werneck GL, Hasselmann MH, Phebo LB, Vieira DE, Gomes VLO. Suicide attempts recorded at a general hospital in Rio de Janeiro, Brazil. Cad S Publica. 2006;22(10):2201-6.

11. Bertolote JM, Fleischmann A, De Leo D, Bolhari J, Botega N, De Silva D, Tran Thi Thanh H, Phillips M, Schlebusch L, Värnik A, Vijayakumar L, Wasserman D. Suicide attempts, plans, and ideation in culturally diverse sites: the WHO SUPRE-MISS community survey. Psychol Med. 2005;35(10):1457-65.

12. Botega NJ, Barros MB, Oliveira HB, Dalgalarrondo P, Marin-Leon L. Suicidal behavior in the community: prevalence and factors associated with suicidal ideation. Rev Bras Psiquiatr. 2005;27(1):45-53.

13. Fleischmann A, Bertolote JM, De Leo D, Botega N, Phillips M, Sisask M, Vijayakumar L, Malakouti K, Schlebusch L, De Silva D, Nguyen VT, Wasserman D. Characteristics of attempted suicides seen in emergency-care settings of general hospitals in eight low- and middleincome countries. Psych Med. 2005;35(10):1467-74.

14. Asberg M, Traskman L, Thoren P. 5-HIAA in the cerebrospinal fluid. A biochemical suicide predictor? Arch Gen Psychiatry. 1976;33(10):1193-7.

15. Hosmer DW, Lemeshow SL. Applied Logistic Regression. New York: John Wiley \& Sons; 1989.

16. Rutz W. The role of primary physicians in preventing suicide: possibilities, short-comings, and the challenge in reaching male suicides. In: Lester D, editor. Suicide Prevention Resources for the Millennium. Philadelphia: Brunner-Routledge; 2001.

17. Canetto SS. Meanings of gender and suicidal behavior during adolescence. Suicide Life Threat Behav. 1997;27(4):339-51. 